\title{
RESTRICTIVE WARTIME LABOR MEASURES IN CONGRESS
}

\author{
MAURICB Winger*
}

Of significance in the history of laws enacted and policies adopted are the measures which fail of passage. Not only do the bills which proliferate in times of stress indicate the contemporary climate of opinion but also they tend to shape, by indirection, the provisions which ultimately emerge in new statutes, the course of executive action, and even the trends in group and individual activity. Accordingly, at this time, when the labor policy of the Federal Government has taken a new departure, a survey of the measures designed by their sponsors to bridle the power of labor organizations, particularly in its relation to the war effort, may well contribute to the understanding of current and subsequent developments in this field. With that end in view, this survey seeks first to trace the interrelation between the dramatic events of the past two years and the appearance of new proposals on Capitol Hill and then to consider the bills which have been introduced in Congress during this period. Because of the number of measures proposed, it has been found convenient to group the individual measures for consideration according to the degree of success they attained. Thus those which prompted no specific action of any kind are first set forth briefly in order to show the range of plans conceived. Following this, the measures which received serious consideration are discussed according to the three main classes into which they fall. In conclusion, the SmithVinson bill is taken up in detail because it not only approached closer to enactment than the others but also because its provisions are so various as to cut across any scheme of classification.

\section{The Impact of Events}

Though the recent agitation over this popularly-termed "anti-labor legislation" is still fresh in mind, its beginnings antedate the defense program as well as the war effort. In fact, rumblings of events to come could be detected in the investigation of the National Labor Relations Board and proposed amendments to the NLRA as early as 1939 and early 1940, but only in a report filed by Mr. Hoffman of Michigan, supported by a numerically weak minority were really extensive amendments advocated. For the majority of the House Committee on Labor reporting on proposed amendments, and even for the preceding Smith investigating committee, the prin-

*A.B., I939, Wm. Jewell College; LL.B., I942, Duke University. Law clerk, Sullivan \& Cromwell, Attys., New York City. Current Decisions Editor, Duke Bar Association Journal, 1941-1942. 
cipal issue was the fairness of the Act and its administration, particularly as to the determination of the proper bargaining unit-the bone of contention between AFL and $\mathrm{CIO}$.

It is significant that even in I940, with the national will as yet deeply divided regarding the still European conflict, news sensations such as the Vultee Aircraft strike brought forth a flurry of verbal response in Congress. However, this was a relatively isolated instance of a truly dramatic work stoppage; the report of the Smith committee, after long hearings investigating the NLRB, caused no major Congressional reaction. The report was charged with distortion of the facts; the Smith amendments received little serious consideration; and when Secretary Perkins' annual report in January I94I, showed a decrease in strikes, the issue began to look moot, if not academic, to a Congress busy with a lend-lease proposal.

However, January, I94I, also brought the beginning of the Allis-Chalmers strike in Wisconsin which caught and held public attention and was undoubtedly responsible for many proposals in Congress. February saw the defeat of an attempt to tack onto the lend-lease bill an amendment suspending New Deal labor laws. Later in the month, Republicans unsuccessfully sponsored a rider to an appropriations bill barring the closed shop. Indicating a widespread sentiment, the Senate of the State of Georgia passed a law barring the collection of union fees from defense workers.

Confronted by the continuance of the Allis-Chalmers strike into March, William Knudsen, wielding considerable influence as head of OPM, reversed an earlier position. In a letter to Chairman Sumners (Dem., Tex.) of the House Committee on the Judiciary, he urged legislation to curb strikes by providing for a cooling-off period.

On March 4, the House Committee on the Judiciary heard Under-Secretary of War Patterson advocate, with the approval of Sidney Hillman of the OPM, an agency similar to the First World War Labor Board. OPM began work on such a plan while ex-Ambassador to France, William Bullitt, in testimony before the same committee, analogized the United States with its Allis-Chalmers strike and other defense stoppages to pre-invasion France. With tension at a peak, President Roosevelt created the National Defense Mediation Board on March 20. Two days later hearings were set for the House Naval Affairs Committee to consider the Vinson bill which, at that time, purported merely to give statutory authority to the Mediation Board in regard to naval construction industries. Congressional friends of organized labor appealed for cooperation to avoid legislation, but before the Allis-Chalmers strike was finally settled by acceptance of the Mediation Board recommendations, plus a faintly veiled threat to use federal troops, a substantial number of new proposals of varying extremes were introduced in Congress and those already pending received much more serious consideration. Even President Roosevelt indicated that the trend was toward a compulsory cooling period for industrial disputes.

However, before the end of March, the crisis passed; testimony before the House Military Affairs Committee was consoling and, with the initial successes of the 
Mediation Board, the Administration policy shifted to "soft talk." During May the tension eased further, although the Gallup poll showed a reaction favorable to cooling period proposals. Though the House Rules Committee, after postponing decision, finally gave the Vinson bill right of way to the floor, attention shifted to personalities with demands in the Senate for the resignation of Madame Perkins.

The North American Aviation strike in June whipped the smoldering coals back to white heat. Although CIO officials branded the strike a wildcat, the crucial position of the affected industry to national defense stirred public opinion to the depths. General Hershey, with Administration approval, obviated some pending legislation by directing draft boards to reclassify for immediate service striking registrants who had been deferred for essential service, and boards reclassified strikers who refused to return to work after the Army Air Corps seized the North American plant. A new flurry of bills appeared in both houses, and strike curbs actually passed the House as riders to the War Department supply bill although they were eliminated in the Senate. On the other hand the plant-seizure bill introduced by Senator Connally (Dem., Tex.) passed the Senate with amendments.

During the summer the strike picture again improved so that when the ConnallyMay bill finally came out of conference and was passed in August, the labor provisions had been entirely eliminated in line with Administration desires.

Conditions were so much improved in September that there was even a pause for retrospect and recrimination during which the AFL claimed credit for killing the measures while blaming the $\mathrm{CIO}$ for their appearance in the first place.

The strikes at Air Associates, Inc, in October shifted the emphasis from labor to management. The Mediation Board accused the company officials of non-cooperation and, when President Roosevelt ordered the plant seized on October 3r, sentiment, by and large, was with the strikers. Concurrently, however, this gain for organized labor was more than offset by the dramatic captive coal mines dispute, and Lewis' defiance of the President. Anti-labor reaction throughout the Nation was so severe that, in addition to offering new bills, many southern Congressmen refused support to the Administration's foreign policy during the crucial debate on repeal of the Neutrality Act unless President Roosevelt would agree to make a definite strike proposal. The subsequent close vote has been attributed to the indefinite response made by Administration leaders.

It is probably not too much to say that the captive coal mines dispute passed the Smith-Vinson bill (which will be considered in detail) although its passage was aided and abetted by strikes at Consolidated, Lockheed, and Vega and by threatened sympathy strikes in almost all aircraft plants on the West Coast. However, when the $\mathrm{CIO}$ members killed the Mediation Board by resigning on November 12 in protest over the Board's decision in the captive coal case, the strong argument that voluntary methods should be given more time was lost.

Pearl Harbor interrupted the momentum which had gathered during the debates. The Senate committees agreed to postpone consideration of their labor bills pending 
the conference of labor and industry called by President Roosevelt on January 2, 1942. When the conference failed to reach a complete agreement and President Roosevelt broke the deadlock on the closed shop issue by ignoring it and promising to set up a war labor board, agitation could scarcely be quelled completely. Senator Connally made plans to press his bill, now replete with labor curbs.

Nevertheless, the industry-labor conferences had succeeded in ruling out strikes, and strikes seem to have fired more public sentiment than any other aspect of the labor problem. Particularly after the initial successes of the newly-constituted National War Labor Board, labor issues might have lost their urgency but for a shift in emphasis which was given direction when the President pointed to the need for longer hours in his annual message to Congress on January 7, I942. This note was caught up by some of the advocates of the older anti-strike measures; several wage-and-hour bills were introduced; and public opinion as evidenced by the Gallup poll, showed favor toward longer hours.

When labor voluntarily gave up double-pay provisions and the passing of time proved the relative effectiveness of the WLB, much of the ammunition for antilabor legislation was removed although some Senators kept up the fight, especially in the form of wage and hour control. By the spring of I942, emphasis had definitely shifted to inflation controls. Accordingly, after President Roosevelt's April inflation message in which he explicitly disclaimed desire or need for labor legislation of any type, both House and Senate committees dropped the pending labor measures, purportedly for the duration.

The vote was close, however, in the House Naval Affairs Committee where some pending measures still had staunch supporters. In the Senate Committee on Education and Labor, majority sentiment favored allowing the WLB a fair chance to prove its mettle without the confusion and pressure of imminent legislation. It seemed to be generally conceded that the continued success or failure of the WLB would determine the ultimate fate of the proposals to be discussed below.

\section{The Scope of Proposed Legislation}

If proposals affecting wages and hours, which are beyond the scope of this survey, are included, well over fifty bills, concurrent and joint resolutions aiming at control or repression of labor were introduced in the last two years. In substance and scope, the measures range from comparative leniency to rigorous severity. Of necessity, most of them prompted no positive action, even at the hands of Congressional committees; however, the objectives of even these are significant.

- On three occasions different sponsors offered bills in the House to define as treason all strikes impeding the progress of national defense during the national emergency. ${ }^{1}$ Somewhat similar, if less drastic, was a proposal that it be a crime to prevent or interfere with the manufacture of necessary government implements or

\footnotetext{
${ }^{1}$ H. R. 4223, 77th Cong., Ist Sess. (1941) by Ford (Rep., Calif.) and H. R. 6057, id., by Welchel (Rep., Calif.).

Unless otherwise indicated, all bills hereafter cited were introduced in the $77^{\text {th }}$ Congress, Ist Session.
} 
munitions. ${ }^{2}$ Several bills sought to restrict the membership of labor unions, aiming particularly at excluding or disfranchising either the alien, ${ }^{3}$ the revolutionist (usually specified as "those opposed to"4 or "advocating the overthrow of"5 the government of the United States), or the more general and inclusive labor racketeer. ${ }^{0}$ A novel measure was introduced by Mr. Wickersham (Dem., Okla.). ${ }^{7}$ It provides that any employees who fail to abide by the decision of the National Defense Mediation Board "shall be replaced by members of the military forces of the United States of comparable qualifications and with good records."

In the Senate, a constitutional amendment was offered "to prohibit denial of the right to work and forbid collection of dues from union members." In the same vein, a Senate proposal would make unlawful "the use of force or violence or threats thereof to prevent any person from engaging in any lawful vocation." Outright repeal of the National Labor Relations Act was advocated by Mr. Hoffman ${ }^{10}$ in the House.

On a descending scale of rigor, other unfruitful bills would prohibit certain political contributions by labor organizations, ${ }^{11}$ would seek to deprive employees engaging in wilful violence in labor disputes of their right to reinstatement under the National Labor Relations Act, ${ }^{12}$ or would require draft reclassification of striking employees engaged in war production. ${ }^{13}$ The latter was rendered unnecessary by General Hershey's order during the North American Aviation strike. ${ }^{14}$

By far the largest number, even of the unconsidered bills, centered around one method or another of mediation of labor disputes, authorization of plant seizure by federal troops, maintenance of the status quo in labor relations, or registration of labor unions. Each of these thoughts was embodied in various bills concerning which there were at least hearings and some of which were favorably reported out of committee and voted upon in one chamber of Congress.

\section{The Proposals Acted Upon}

As might well be expected, the approach and attitude of the several Congressional committees involved shows a wide divergence. In the Senate, the Committee on

${ }^{2}$ H. R. 7582, 76th Cong., 2d Sess. (1939). This bill anticipated the spirit of things to come. It was filed on Oct. 12, 1939, by Hoffman (Rep., Mich.).

${ }^{8}$ H. R. 4406, by Woodruff (Rep., Mich.). 'H. R. 5035, by Ramsay (Dem., W. Va.).

"H. R. 5081, not listed by author in the Congressional Record's "History of Bills."

'S. J. Res. 64, by Reynolds (Dem., N. C.) and H. R. 6777, 77th Cong., 2d Sess. (1942) by Gibson (Dem., Ga.). The fate of H. R. 5580, by Landis (Rep., Ind.) is an exception among bills of this class. Though the House took no action, the bill was actually reported out favorably by the House Committee on Labor on March 13, I942, H. R. REP. No. 1897, 77th Cong., 2d Sess, which stated that the bill's purpose was "to prevent subversive individuals from representing employees in labor unions." Such individuals were defined at length, and the Attorney General was given jurisdiction to determine subversiveness after notice and hearing. Chairman Norton (Dem., N. J.) dissented from the bill on the ground that the Attorney General disapproved it.

\footnotetext{
TH. J. Res. 247.

${ }^{8}$ S. J. Res. 106, by O'Daniel (Dem., Tex.).

S. I $81 x$, by O'Daniel, and also H. R. 1403 and H. R. 6069 , both by Hoffman.

${ }^{10} \mathrm{H}$. R. 1404 .

${ }^{21}$ Inter alia, in H. R. 4392, by Bennett (Rep., Mo.). $\quad{ }^{28}$ H. R. 4637 , by Halleck (Rep., Ind.).

${ }^{13}$ Inter alia, in H. R. 6826, 77th Cong., 2d Sess. (1942) by Colmer (Dem., Miss.).

${ }^{24}$ See p. 504, supra.
} 
Education and Labor which has carried the bulk of the burden in that chamber, took a step making for orderly and systematic consideration when its chairman submitted a Senate resolution in May, r941, calling for "basic data for the formulation of a policy toward strikes in defense industries in the United States together with facts as to the extent, duration, and severity of defense strikes, and the causes therefor; also a summary of the State and Federal law and jurisprudence which define the rights and status of labor insofar as they relate in any way to strike situations." ${ }^{15}$ This useful document emphasizes, among other things, the extent to which states have already been experimenting in the field and the variety of approaches they have taken. Exponents of federal proposals have stressed the heterogeneity of these measures in advocating that uniform federal legislation supplant them by pre-empting the field.

To avoid a distorted picture, it should be mentioned that even in the midst of powerful agitation for restrictions on labor, proposals were also considered seeking to preserve and strengthen labor's rights and privileges. In fact, the long pending Oppressive Labor Practices Act, which was sponsored by Senator LaFollette (Prog., Wis.), passed the Senate in October, 1939. Although this bill died at the hands of the House Committee on Labor, legislation to benefit labor has also been initiated in that chamber. ${ }^{16}$ Furthermore, LaFollette reintroduced the bill in the Senate in April, 1942, concurrently with the introduction of its counterpart in the House ${ }^{17}$ by Mr. Sauthoff (Prog., Wis.). These measures exist as, inter alia, a counterthreat against restrictive labor legislation.

As has already been mentioned, the greatest number of bills which received serious consideration involved union registration, plant seizure, or mediation, either singly or in combination. Perhaps the first was the least controversial of these three. Trade association registration was usually included to avoid the accusation of bias.

\section{a) Registration}

This proposal was brought to a head by the report of the House Naval Affairs Investigating Committee which stated that the labor unions answering its questionnaire had total net assets of $\$ 82,594,955$ on March I, x94I, an increase of $\$ 10,679,294$ since October $x$, 1939 , the beginning of the defense program. ${ }^{18}$. Accordingly, the Committee's recommendation:

\footnotetext{
${ }^{28}$ SEN. Doc. No. 52. The House Committec on the Judiciary has also compiled a useful reference document for this field of legislation in the form of lengthy, exploratory hearings on Delays in National Defense Preparations which are published in two parts (Part I: Feb. 17, r8, 19, 20, 24, 25, and 28 and March 3, 6, XI, 13, 14, 18, and 24, I94I; Part II: May 7, 8, 12, and I9) 77th Cong., Ist Sess. (I94I).

${ }^{20}$ LaFollette's bill (S. 1970) would prevent the use of labor spies, strike-breakers, oppressive armed guards, and industrial munitions. In the House, H. R. 4874 , by O'Brien (Dem., Mich.), would provide for the construction needed to strengthen national defense and thereby promote the economic security of the United States by complete and efficient employment of labor.

${ }^{17}$ H. R. 6928, 77th Cong., 2d Sess. (r942).

10 The AFL has attempted to minimize the significance of these figures by the fact that most of its treasury is held in trust for various benefits to its members. Hearings before House Iudiciary Committee on Delays in National Defense Preparations, 77th Cong., rst Sess. (194I) 396.
} 
The tremendous financial gains made by labor organizations during the period of the defense effort and the vast amount of funds and assets in their treasuries present an astounding picture of concentration of wealth, a situation heretofore only associated with industry and finance. These vast tax-exempt funds reposing in the treasuries of labor organizations, many of which by strikes and work stoppages have delayed and in instances even obstructed the defense program, present a problem which the committee feels should well be considered by the Congress. The committee recommends that suitable legislation be enacted requiring all labor unions (along with other special interest groups) to register with a suitable governmental body and to furnish pertinent information concerning their officers, members, and financial condition at periodic intervals.

By requiring information as to the use and disposition of these large sums of money, these bills were also intended, in part, as a legislative answer to the newspaper columnist campaign against labor racketeering. The first successful appearance of such a measure was. in the Smith amendment to the Vinson bill in which form, the registration proposal passed the House without having ever passed through the hearing stage of legislation. However, in January, 1942, when it became apparent that there was no immediate likelihood, if any, of Senate action on a bill embracing such a variety of far-reaching changes as were included in the House bill, Representative Vinson (Dem., Ga.) reintroduced, with a few alterations, the registration provisions alone. ${ }^{10}$ At this time, several similar bills were already pending in both houses, and the added weight of Vinson's proposal finally brought forth hearings before a subcommittee of the House Committee on the Judiciary in March, I942.

As would be expected, both the AFL and the CIO, as well as trade associations and chambers of commerce, ${ }^{20}$ testified against the bill, though the latter with the least vigor. Specifically, labor organizations argued that the bill was entirely unnecessary as a guard and ineffective as protection against labor racketeers, first, since any union member already has a right to demand a detailed financial statement from his union which is much easier to obtain "in the union than it would be in the case of municipal, State, or Federal government"21 and, second, "registration plans can make no claim that they are related to the problem of labor racketeering [because] racketeers ... flourish primarily by extortion or payment from employers . . . [and] extortion payments make no appearance in the union's financial records."22 In addi-

${ }^{20}$ H. R. 6444, 77th Cong, 2d Sess. (1942).

${ }^{20}$ The measure which passed the House applied only to labor. Sec H. R. 4r39, \$\$8, 9.

${ }^{21}$ Hearings before the House Judiciary Committee on H. R. 6444 (hereinafter cited as "Hearings"), 77th Cong., 2d Sess. (1942) 25. This claim is subject to considerable doubt in the light of Mr. Arnold's testimony as to a union response to such a request. Id. at 86.

\$2 Id. at x6. Section 3 (a) of H. R. 6444 provides: ". . . each labor organization and trade association shall file with the Secretary of Commerce a registration statement setting forth . . .

(I) The names, addresses, compensation, and terms of office of the . . principal officers of the registrant, and . . . members of its governing body; . . .

(3) Financial information, showing in detail the assets and liabilities of the registrant as of the close of its preceding fiscal year, its reccipts and expenditures during such fiscal year, and such other information as the Secretary of Commerce may, by the regulations issued pursuant to this Act, require; . . .

(5) In the case of a labor organization, the names and addresses of any employers with which such organization has any agreement or agreements, and the terms thereof, relating to wages, rates of pay, hours of work, or other conditions of employment of employees represented by such organization; 
tion, it was urged that such practice is "obviously in violation of many State and Federal statutes."

It was also urged that Section $3(a)_{5}$ of the bill, requiring a list of all employers with whom the union has an agreement and the provisions thereof, would serve no useful purpose after it was furnished and "would impose an extraordinary additional office force necessitating without doubt an increase in the levying of dues [creating] disturbing thoughts among the loyal members as to the need for any increase in dues.",28

The penalty provisions of the bill were opposed as heavy, ambiguous, and subject to too much discretion in the hands of the Secretary of Commerce, who, it was claimed, might, by technical requirements, find enough violations "to empty a union treasury and put all the officers of the organization in jail."24

The most urgently pressed and oft-repeated argument against the bill was a broadside at its motives and net practical results. Thus:

The sponsors of measures of this type must know full well that in the normal functioning of a democracy, the relationship between an employer and a labor organization is one of collective bargaining, bargaining implying precisely what it means in its similar use in other fields. In the bargaining process it would obviously be greatly to the employers advantage if he knew to the dollar the extent of the union's financial strength, its ability to support a strike if a strike becomes necessary, its ability in general to hold out for better working conditions, or to yield to those dictated by the employer. ${ }^{25}$

The counterargument by Vinson was that employers are required to disclose their financial strength by the Securities Exchange Act and in tax returns so that a corresponding mandate to the unions is only equitable and is owed to union members and the public at large. ${ }^{28}$

Assistant Attorney General Thurman Arnold, called as a witness, indorsed the bill as far as it went, and introduced a significant additional consideration. Having stressed the unbridled power of labor, he concluded:

In other words, when you come to look at the entire picture, we see a situation which is putting a very substantial handicap upon the distribution of all civilian necessities,

(6) A statement of the purpose for the registrant was organized and a description of its present activities; and

(7) Such other information as the Secretary of Commerce may consider necessary to cffectuate the purposes of this Act.

The registrant shall, at the same time, file with the Secretary of Commerce a verified copy of its constitution, by-laws, and other governing instruments."

S. 2042, a bill of similar import would require, in addition: "initiation fees; annual dues charged each member; assessments levied during the past twelve-month period; limitations on membership; number of paid-up members; date of last election of officers, method of election; the vote for and against each candidate for office; and the date of the last detailed financial statement furnished all members and the method of publication or circulation of such statements."

${ }^{23}$ Hearings, 3 .

9s Id. at 63. The bill provides a fine of $\$ 5,000$ and I year's imprisonment for labor union or trade association officials responsible for, or having knowledge of, a failure to file a registration statement or report or the making of a material misstatement of fact therein. The Smith-Vinson bill merely disqualified a union which failed to register from representing employees in collective bargaining.

${ }^{20}$ Hearings, 17.

${ }^{20}$ See id. at $4,5,94-95,98$. 
depending, of course, on how strongly the union is organized in a particular place, which is destroying the property and the businesses of independent businessmen, and which is impeding the distribution of housing, and particularly the distribution of food, and is doing it at a time when we are trying to save these independent organizations, and I think it is a very serious problem. Certainly the registration of unions would have some effect on it. Whether that would go far enough I simply leave to the judgment of the committce. I think I would be entitled to say that my belief is that it does not go far enough.

I will introduce in the record the recommendations which I made before the Temporary National Economic Committee.

These recommendations provide, in brief, that labor shall be permitted to use its organized power in any way, subject, of course, to local police regulations, provided that the objective was a legitimate objective for the union to use its power for. I describe legitimate objectives as anything which had some direct connection or some reasonable connection with wages, hours, safety, health, and conditions of employment; and that activities which had no connection with these objectives were illegal. Such legislation would eliminate the things I am talking about, because I consider them not the legitimate objectives which a labor union should pursue either on behalf of the public or for the good of the labor union. ${ }^{27}$

At the last session of the hearings, Mr. Vinson presented a summary rebuttal which purported to answer all of the objections, ${ }^{28}$ both specific and general, which the hearings had produced. First he emphasized the improvements in this bill over similar provisions in the Smith-Vinson, H. R. 4I39, bill which passed the House and which was temporary, emergency legislation, whereas the proposal under consideration would be a permanent addition to the federal labor laws. H. R. 4r39 provides for registration under the National Labor Relations Board which "has a very specific duty, which provides for the protection of the rights of collective bargaining by groups of employees, and the safeguarding of the rights of free and untrammelled self-representation. The danger of confusion is immediately apparent." The present proposal substitutes the Secretary of Commerce to receive registration statements.

This "improvement," it should be mentioned, was very strongly opposed by labor on the ground that the Department of Commerce not only has no familiarity with labor problems but also is a "businessman's department." The provision which requires production of "such other information as the Secretary of Commerce may at any time consider necessary to effectuate the purposes of the Act" (\$3(d) (3)) was also opposed as unpredictable in its potentialities of harm to labor organizations. ${ }^{20}$

Vinson disposed of the general objection against government control as, inter alia, the same that was raised by business to the Securities Exchange Act and pointed to the beneficial effect of the SEC's work as conclusive answer. He argued that financially weak labor unions need not be exposed to economic battle with stronger employers on the ground that "if such facts were made to appear in a petition to the Secretary of Commerce, it is certain that he would consider the case one in which it would not be to the public interest to disclose the financial data, provided, of

${ }^{27} \mathrm{Id}$. at 77. ${ }^{28} \mathrm{Id}$. at 92-102.

${ }^{59} I d$. at $63-65$. The purposes of the Act include, ". . . to safeguard and protect the right of individual employees, employers, and the public against abuse of these rights of self-organization. . . ." \$r. 
course, there were no other circumstances which should be submitted to the purifying light of public examination."30 To the argument of lack of necessity for publication of financial statements, Vinson replied that in such cases the requirement should be no burden to the unions, but he stressed the fact that Mr. Scharrenburg (of the AFL) "receded from his position and avoided a direct request for a statement showing what each national union does in the matter of furnishing its members with a financial report."

Against the additional argument that the bill would be an "entering wedge by which enemies of labor would eventually crush all unions," Vinson pointed to the New Deal labor record. He concluded by citing as precedent the English voluntary registration system covering $75 \%$ of the union membership of Great Britain and by reiterating the bill's preventive rather than corrective objective. ${ }^{81}$

\section{b) Plant Seizure Proposals}

This form of legislation, urged particularly by Senator Connally, would give explicit statutory authority to the President to seize defense plants when he "finds, after investigation, that the national defense program will be impeded or delayed by an existing or threatened failure of production at such plant as a result of a strike or other labor disturbance or other cause, and that the exercise of such power and authority is necessary or desirable in the public interest."

This was first proposed in June, 1941, as an amendment ${ }^{32}$ to the Selective Training and Service Act of r940. Without any specific labor provisions, it was reportedly approved by Administration leaders as a symbol of the popular approval of the Army's taking over struck defense plants. ${ }^{33}$ As has been remarked, ${ }^{34}$ a substantially similar measure passed the Senate two days after the Army Air Corps took over the North American Aviation plant. There were no hearings or committee reports on either of Mr. Connally's proposals. The bill simply came up on the floor of the Senate as an amendment. ${ }^{35}$ Before passing the Senate, Connally's proposal was amended three times. The Byrd amendment specified that "strikes or lockouts that impede or delay the national defense effort are contrary to sound public policy, and ... are ... condemned," and that "strikes or lockouts in such industries in which either side refuses to recognize arbitration or mediation ... are ... condemned." The LaFollette amendment added:

${ }^{30}$ The bill provides that ". . . the Secretary of Commerce may treat as confidential, or restrict the inspection of, any information contained therein which he shall not deem in the public interest to disclose." \$7.

${ }^{01}$ There is, as yet, no committee report on this measure. The most recent action of any significance in this field was in April, 1942, when Senator O'Mahoney (Dem., Wyo.) introduced a new Federal Charter Compliance Act (see 88 Cong. Rec., April 6, I942, at 346x, for text of S. 2438) which, in addition to its corporate provisions, provides ( $\$ 6$ ) that the Commission shall issue a certificate of statutory compliance to any labor union if its charter provides for annual election of officers, free nominations, supervision of elections by members, independent public audits at least biennially, and a \$ro maximum initiation fee.

${ }^{30} \mathrm{~S}$. 1600 , by Connally.

${ }^{33}$ See N. Y. Times, June II, 194I, p. 14, col. 3.

31 P. 504, supra.

${ }^{08}$ Some Senators pointed out that such a procedure would probably cause mistakes which would be regretted in time to come, 87 Cong. Rec., June 15, r941, at 5185. 
The Congress hereby further declares that complete cooperation between government, management, and labor can best be achieved by the whole hearted acceptance of the principles of collective bargaining and the recognition of the rights of employees to designate representatives of their own choosing, for the purpose of collective bargaining, without interference through unfair or oppressive labor practices.

The Ball amendment was opposed by Senator Connally on the ground that he did not want his amendment "diluted, denuded, dehorned, and de-everything in order to get it through ${ }^{35^{2 \prime}}$; however, it was passed by a majority of two votes. It required that before seizing a plant, the President must make the additional finding:

That either or both parties to such [labor] dispute have failed to utilize existing government conciliation and mediation facilities in an effort to settle such dispute, or that despite the use of such facilities, the dispute has not been settled and a failure of production exists or is threatened.

These provisions were referred to the House where they were ignored, partly due to the fact that the House was considering a more stringent measure along similar lines in the form of the May amendment to the Selective Training and Service Act. This measure broadened the basis for government intervention in defense plants. ${ }^{30}$ It was opposed by the Administration and defeated on the floor of the House. In the House-Senate conference a combination of the Connally and May proposals relating to plant-seizure was inserted again. Thereupon the House voted to return the bill to conference with instructions to oppose the plant-seizure provisions. In August, I94I, the conference agreed to delete the labor provisions after which the bill passed both chambers.

However, in November, 194I, Senator Connally reintroduced a similar measure with new provisions to freeze the status quo in labor relations during government operation of any plant and to provide for a "Defense Wage Board" to handle wage adjustments during government operation. ${ }^{37}$ Hearings were held on this bill (not published at this writing) and a favorable report was filed in December, r94r. In contrast to Vinson's registration bill, this report stresses the emergency and temporary character of this Act. ${ }^{38}$

The President is required, before acting, to find, upon investigation, "that there is an interruption of the operation of such plant as a result of a strike or other labor disturbance or other cause, that the national defense program will be unduly impeded or delayed by such interruption, and that the exercise of such power and authority

${ }^{354}$ Ibid.

${ }^{36}$ In addition to authorizing government intervention in case management refused to conciliate or mediate, the bill would make it unlawful to attempt to prevent by forec or threats thereof, any person from accepting or continuing employment in any defense plant. Furthermore, in the event of a work stoppage through "subversive influences or otherwise, not constituting a refusal," then the President would be empowered to order the plant to resume production immediately. He could enforce this order through the Secretaries of War and Navy, and "afford protection to all persons engaged in the operation of such plant or industry who voluntarily desire to work in such plant." This power was to continue during the emergency but it was not to be construed as giving any defense worker the status of a government employee. See N. Y. Times, June 25, 1941, p. ro, col. 4.

${ }^{87}$ S. 2054 .

${ }^{38}$ See Sen. REP. No. 486, 77th Cong., Ist Sess. (I94I). 
is necessary to insure the operation of such plant in the interest of national defense. ..." ( $(\mathrm{I})$. (It will be noted that the restrictive amendments added to the first Connally bill on the Senate floor were omitted.)

Provision is made for returning plants to their owners "whenever the President determines that the plant will be privately operated in a manner consistent with the needs of national defense." $(\S \mathrm{I})$. Section 2 aims at avoidance of the closed shop problem during government operation ${ }^{39}$ by freezing all labor relations although it does not prevent the Government from improving working conditions. Finally, the report fairly characterizes the bill's last section as follows:

Section 3 establishes a Defense Wage Board which is to be composed of three members who shall be appointed by the President by and with the advice and consent of the Senate. Upon petition filed with it by a majority of the employees of any such plant or their representative the Board is directed to make an investigation of the wages paid at such plant, the cost of living in the community . . the wages established for work of like or comparable character in the industry, and such other factors as the Board may deem necessary or desirable in the public interest. If the Board finds that the wages paid at such plant are not fair and reasonable it is directed, with the approval of the President, to order such readjustments of wages as it deems will fairly and reasonably compensate such employees for their work. . . . Subsection (e) ... terminates the authority of the Board upon the expiration of the unlimited national emergency....

The real significance of this measure lay not so much in its own proposals which have raised relatively little controversy. Its great importance was due to the strategic preferential position which it obtained in the Senate. Senator Connally was able to obtain a motion to take up his bill on the floor and was in a strong position to secure its passage. At the same time, to bring such a measure out for consideration would have made it in order to introduce a wide variety of amendments from the floor since its own proposals, though mild in themselves, touched on enough different aspects of labor control to make the most stringent and repressive amendments germane to the measure under discussion. The insistent objection which Senator Byrd (Dem., Va.) made on the floor of the Senate when Connally withdrew his motion in April, 1942, makes this procedural significance of the Connally amendment abundantly clear. ${ }^{40}$ Apparently it was conceded that this afforded the last good chance to get Senate consideration of any repressive labor legislation after the Administration had definitely taken an opposing stand in President Roosevelt's anti-inflation message to Congress in April.

\section{c) Proposed Limitations on the Right to Strike}

The proposals most numerous and subject to the bitterest controversy are those which would, by one method or another, limit, supervise, or postpone the right to strike or lockout. The related bills range in degree of severity from the rather mild

so After seizure, the plant "(a) shall be operated under the same terms and conditions of employment which were in effect at the time possession of such plant was so taken, or (b) in the event operation of such plant is interrupted or stopped at such time, shall be operated under the same terms and conditions of employment which were in effect at such plant immediately preceding such interruption or stoppage."

to Sce 88 Cong. Rec., April 12, 1942, at 3862 et seq. 
bill (S. 683), introduced by Senator Ball (Rep., Minn.) and reported favorably by the Senate Committee on Education and Labor, to the most far-reaching Smith-Vinson bill (H. R. 4I39), passed by the House and consolidating most of the various proposals which had been made in separate bills over a considerable period of time.

Although no action has ever been taken on the Ball bill by the Senate as a whole, it is the only strike legislation which was reported out of committee in the Senate.11 There is little danger of inaccuracy in saying that this bill, as reported, represents the most thoroughly considered piece of proposed legislation within the scope of this survey. Senator Ball's first effort was S. 4434, introduced in November, x940. With several modifications he reintroduced the measure as S. 683 on January 3I, r94I. Thereafter he added three amendments. After reports from several government departments had been received, committee hearings were held from May 6 to 29, I941, compiling over three hundred pages of testimony and resulting in a complete rewriting of the bill to meet many of the objections raised by labor in the hearings.

As finally formulated, S. 683 aims to state a clear national policy and a set of procedures for settling of labor disputes. With the exception of Section 9, it is not temporary legislation nor is it restricted to defense industries. It embraces all but the railway industry which has its own mediation act. The committee takes the position that "almost endless controversy [is] bound to arise over any attempted definition of 'defense industry'."42

During the hearings, it was repeatedly pointed out that strikes cannot be successfully be outlawed, even temporarily, (citing the examples of Kansas, New Zealand, Canada, and Britain) and, accordingly, the bill embodies no penalty provisions against strikes. It was argued that the "executive branch of the Government under the Selective Service Act, the Property Seizure Act, as well as under the President's constitutional powers as Commander in Chief of the Army and Navy now has adequate authority to obtain resumption of production in a critical defense plant once production has halted...."43 It was also felt that this type of legislation was more likely to enlist the support of labor, while serving as notice of a last chance for voluntary cooperation.

Roughly, the bill sets up the following procedure: Whenever a change in wages, hours, or working conditions is sought by either labor or management, the moving party is to give 30 days notice in writing. Within five days, a meeting is to be arranged between them for direct negotiations. ${ }^{44}$ If this fails, the dispute goes to the Conciliation Service of the Department of Labor, which however, may intervene on its own motion at any time. If still no settlement is reached, the next step is reference to the National Defense Mediation Board (the then existing Board or its successor). No publication is to be made at this point, but, if the added prestige of the Board is unavailing, the points still in controversy are referred to a Labor Disputes Commis-

${ }^{11}$ SEN. REP, No. 847, 77th Cong., Ist Sess. (I94I).

"Id. at 3 .

"This step was inserted to meet the objection that the bill prevented true collective bargaining by imposing goverament regulation. 
$\operatorname{sion}^{45}$ which investigates ${ }^{46}$ and publishes findings of fact and recommendations as to settlement of the points in dispute. The rest is left to the force of public opinion.

The objection was stressed during the hearings that forbidding strikes to be called while the above negotiations were in progress would, in effect, destroy collective bargaining since management would always take the opportunity of putting off the payment of wage increases. Since many contracts are of short duration, the delay would give management a great advantage. To meet this argument, Section ${ }_{4}(f)$ of the final draft provides that, where arbitration is agreed upon, the employer must agree in writing to make the wage provisions of the final settlement retroactive at least to the date of original agreement, or in "any case in which both parties... accept the recommendations for settlement made by the Commission . . . the employer shall make the wage provisions of such settlement retroactive at least to the date when the points in controversy were referred to the Commission." Of course this still leaves what might be a considerable period of time unprovided for, since only "reasonable" speed is required at each step in the process between the original 30-day notice and the final transmission of a dispute by the Mediation Board to the Commission. During all this time, in the absence of agreement to arbitrate, no retroactive provision would apply.

Section 6(a), preserving the status quo, is opposed by labor on the ground that it puts all negotiations on the basis of strike disputes rather than voluntary cooperation. The closed shop problem is approached rather uniquely through Section 9, the only temporary part of the bill, which provides:

(a) ... it shall be unlawful for any employer engaged in a business affecting interstate or foreign commerce or the national defense to enter into any contract or agreement with his employees, or any group thereof containing a provision that membership in a labor organization shall be a condition of employment by such employer, if such organization or any of the employees to whom such provision is applicable has, after the date of enactment of this Act and within one year prior to such employer's entry into such contract or agreement, engaged in a strike or stoppage of work to secure such condition of employment, unless such contract or agreement is a renewal or extension of a contract or agreement containing a similar provision.

Paragraph (b) declares contracts violating the section void and unenforceable, and subjects employers entering into such a contract to a fine of not less than $\$ 1,000$ nor more than $\$$ Io,000. The committee report remarks as follows:

This provision does not outlaw strikes for closed shops. It makes such strikes completely futile. It does not freeze the closed shop because employers could still agree without a strike to a closed shop. Neither could an employer use the provision in an attempt to deny renewal of an existing closed shop agreement because his employees could then strike to force him to renew.

\footnotetext{
${ }^{65}$ Composed of three members appointed by the President with advice and consent of the Senate, for terms of six years, and salary of $\$ 10,000$ per year. It would have power to investigate labor disputes and make recommendations for settlement, arbitrate disputes submitted to it, and adjudicate disputes as to proper construction of provisions in existing collective bargaining agreements.

${ }^{\circ}$ Subpena power is given to the Commission by Section 7 .
} 
Organized labor opposes this provision and most of the rest of the bill, whereas the representatives of management who appeared before the committee, including the National Association of Manufacturers, feel that it does not go far enough and would broaden it considerably. Such government officials as testified favored at least the bill's objectives. ${ }^{47}$

\section{The SMITH-Vinson BILL}

During the height of the public indignation which the captive coal dispute aroused throughout the nation, the Vinson bill, H. R. 4139, reached the floor of the House of Representatives, received the addition of the Smith amendment, and was passed. The history of this measure is revealing. It was first introduced on January 29, I94I, as H. R. 2850. On March 2r, it reappeared as H. R. 4139. Opponents of the measure have alleged that the original bill was deliberately framed in terms of "naval-defense contractors" to keep it under the watchful care of its sponsor (chairman of the House Naval Affairs Committee) and out of the hands of the Committee on Labor. Certainly the Committee on Labor has put to sleep a considerable number of similar proposals ${ }^{48}$ but, be that as it may, the Naval Affairs Committee, under Mr. Vinson, began hearings April r5, r94I, with testimony from Secretary of the Navy Knox and John Green, President of the Industrial Union of the Marine and Shipbuilding Workers of America (CIO affiliate). The committee next met on April I7, but no other outside witnesses were called to testify, and it proceeded to consider drafting amendments and terminology.

The testimony of Mr. Knox was equivocal. He favored a cooling-off period but opposed any coercion. Mr. Green opposed the bill on general principles-first, as unnecessary in view of the production accomplishments already realized without additional legislation; second, as an abridgement of labor's rights on the ground that "compulsory arbitration is no better than rule by edict . . . even if it is only exercised for a limited time."48

There were some minor changes in committee in addition to the substitution of "national-defense contractor"50 for the original "naval defense contractor."

\footnotetext{
${ }^{47}$ Mr. Leiserson of the National Labor Relations Board felt that the bill would not effectuate its stated policy but many of his specific objections were corrected in the final draft. Mr. Bruere of the Maritime Labor Board endorsed the policy of mediation but desired to preserve the Maritime Labor Board. Govcrnor Stassen of Minnesota favored the bill as a copy of Minnesota's statute which he considered successful.

${ }^{18} \mathrm{~A}$ memorandum from that committee lists the following restrictive labor bills on which no action was taken: in the rst Session of the 77th Congress (1941): H. R. 4406, 4637, 4874, 5035, 5015, 6068, $6074,6075,6039$, and H. J. Res. 247; in the 2 d Session (I942): H. R. 6689, 6777, 6796, 8045, and 9507. 849.

"Hearings before the House Naval Affars Committee on H. R. 4139, 77th Cong., Ist Sess. (1941)

${ }^{80}$ Section 302, "The term 'national defense contractor' means-

(I) an employer engaged in:

(A) the production of arms, armament, ammunition, implements of war, munitions, clothing, food, fuel, or any parts or ingredients of any articles or supplies; or facility;

(B) the construction, reconstruction, repair, or installation of a building, vessel, plant, structure, or under a contract entered into . . . by the Secretary of War, the Secretary of the Navy, the United State Maritime Commission, or by an officer or employee of [any of them] or under contract entered into ... by the Sccretary of Treasury or by [a Treasury] officer or employee . . . which the Sccretary of the
} 
In rough outline, the bill requires national defense contractors and their employees to adopt the following procedure to settle their disputes: they must first try to agree by conference or utilization of applicable procedure specified in their collective bargaining agreements. Failing this, either party may request assistance of the Conciliation Service of the Department of Labor. Interested parties are then notified by the Secretary of Labor and are required to submit their claims in writing and attempt a settlement. If, after not less than five days, any party considers settlement impossible, he may give notice of an intention to strike or lock out. Such notice automatically transfers the dispute to the National Defense Mediation Board where every effort must be made to reach a settlement. Within twenty days after such notice, the Board must render a report to the public if settlement is reached. Until the requisite notice has been given and the Board's report published, strikes or lockouts are unlawful. Thus the minimum cooling period is 25 days. To maintain the status quo during this period, it is further made unlawful for an employer, without written consent of his employees, to continue in effect any change in working conditions which results in a labor dispute.

In reference to closed shops, the bill forbids a defense contractor to enter into a closed-shop, preferential-shop, or any similar agreement with any labor organization, unless such an agreement was in existence on the date of enactment of the bill $(\$ 307)$.

It is sought to eliminate subversive activities by the much criticized vehicle of forbidding $(\$ 308(\mathrm{a}))$ any national defense contractor to employ or retain anyone "whom such contractor has reasonable cause to believe-

(I) teaches, advocates, or believes in, or has at any time advocated or believed in the duty, necessity, or propriety of controlling, conducting, seizing, or overthrowing the Government of the United States by force, violence, military measures, or threats thereof; or

(2) is, or at any time was, a member of, or is soliciting or advocating or has at any time solicited or advocated membership in, the Communist Party, the Young Communist League, the German-American Bund, or any organization which teaches, advocates, or believes in, or at any time has taught, advocated, or believed in, the duty, necessity, or propriety of [the acts listed in par. ( $I$ )]; or

(3) is disseminating or distributing, or at any time has disseminated or distributed, any book, pamphlet, leaflet, or other item of written, printed, or graphic matter (A) teaching or advocating the duty, necessity, or propriety of [the acts listed in par. (I)]; or (B) soliciting or advocating membership in the Communist Party, the Young Communist League, the German-American Bund, or any organization [of the sort described in par. (2)].

In addition, all present and prospective employees of defense contractors are required to make affidavit that they are not individuals of the proscribed character.

Treasury at any time by order declares is a contract necessary to the national defense, or under a contract with another national defense contractor which [any such Secretary or the Commission], at any time by order declares is a contract necessary to the national defense; or

(2) an employer engaged in the production or handling of any article described in Proclamation Numbered 2237 promulgated by the President on May 1 , 1937; but such term shall not include an cmployer engaged in the production of farm products on a farm." 
Lastly, if the Board decides that an employer has reason to believe that a worker who has been discharged or refused employment is of that character, the NLRB cannot order his reinstatement but he may within 30 days apply to the Mediation Board for reinstatement on showing good character.

The penalty provisions call for fines of not more than $\$ 5000$ or imprisonment for not more than a year or both and the termination date is set at three years from date of enactment or termination of the national emergency, whichever occurs first.

A strong minority report was filed against the bill by Representative Magnuson with the concurrence of five of the 30 members of the committee. Therein it is charged that "this legislation was rushed through the committee without adequate notice to the major labor unions. ... Forty-nine hours after the telegram announcing the opening of hearings was sent to Mr. Murray ... hearings on the bill had been closed. Seventy-eight hours after the telegram was sent, the bill was reported out of committee.... It is also true that no employer was heard ... nothing was announced in the press or in any other fashion regarding hearings.... It is almost unthinkable that the most important piece of legislation to come before Congress in many years would conclude hearings with but two witnesses."

The minority report objected specifically to the declaration of policy that employees "in the exercise of their rights guaranteed under the National Labor Relations Act should not use coercive measures of any kind to induce persons to join their organizations nor to induce employers to bargain therewith." It is alleged that, in practice, this will mean the amendment to the NLRA which Representative Hoffman urged but which was specifically rejected by the Committee on Labor and the House. The minority fears that "coercive measures" without any statutory amplification might be construed by adverse courts in accordance with the earlier common law torts doctrine so as to include even peaceful picketing, and thus bring about the destruction of the fundamental purposes of the NLRA. The report adds:

Equally astounding is the last phrase in this paragraph, "nor to induce employers to bargain or deal therewith." Strikes, picketing, peaceful persuasion, or even threats of strikes, could be construed under this section, to be coercive measures, and are all outlawed. ${ }^{2}$

It is claimed that Section $30 r(e)$ and $(f)$ not only freeze the closed shop situation, but also "wages, hours, and other conditions of employment. . . . Insofar as new business is concerned, no closed shop could be maintained . . . even if all parties agreed."53 The report concludes that freezing the open and closed shop is an

${ }^{62}$ H. R. REP. No. 427 , pt. 2, 77th Cong., Ist Sess. (I94I) 2 et seq.

${ }^{62} I d$. at 5 .

${ }^{53}$ Such an interpretation as to wages, hours and working conditions requires a rather strained construction of the statutory language which is:

(e) In the establishments of national defense contractors where the union shop exists, such condition should continue, and the union standards as to wages, hours of labor, and other conditions of employment should be maintained; and

(f) In establishments ... where union and nonunion employees now work together, the continuance of such condition should not be deemed a grievance, but this declaration is not intended in any manner to deny the right, or to discourage the practice of the formation of labor organizations, or the 
unjustified subterfuge to freeze one and destroy the other. The compulsory mediation and cooling period is attacked as contrary to national policy, impractical, unnecessary, and as placing a weapon in the hands of the employer by which he may complicate unreal disputes and drain away the union's financial strength. The sections of the bill aimed at subversive elements are violently attacked on the ground that their nebulous wording would allow employers almost unrestricted power to abuse fundamental civil rights and to ignore the NLRA by discharging active union members and claiming "reasonable cause to believe" that they had "at any time" in the past "believed in the overthrow of the government" or advocated membership in the forbidden organizations..$^{54}$

These reports were filed in April, 1941. In November, shortly before the bill came before the Committee of the Whole House, Vinson filed a supplementary report ${ }^{55}$ which discussed a completely amended proposal. The "subversive" provisions were eliminated entirely, the policy statement under attack was deleted, the penalty provision was abandoned in favor of enforcement by federal injunction at the instance of the Attorney General. It is a fair generalization, if not an understatement, to say that the entire proposal was toned down and softened appreciably.

Acutely aware of the Senate report on the Ball bill, the Naval Affairs Committee reports on the Vinson bill, and constantly mindful of the increasing pressure caused by the captive coal dispute, the House Committee on Labor finally produced a favorable report ${ }^{50}$ on a mediation measure by Representative Ramspeck (Dem., Ga.). Mild by comparison with its fellow travellers, it provided that the Mediation Board should take jurisdiction of any labor dispute not within the purview of the Railway Labor Act, which it finds "substantially affect the National defense and cannot be expeditiously adjusted by collective bargaining or other conciliation and mediation procedures." (\$4). The Board is then to attempt a settlement or to induce voluntary arbitration. If unsuccessful, findings and recommendations are to be published. After the Board takes jurisdiction, the status quo is to be preserved by cease-anddesist orders from the Board, enforceable by the Attorney General in federal district courts.

The Ramspeck bill also contained a plant-seizure provision similar to the first Connally amendment. ${ }^{57}$

The original Vinson bill came before the House on December 3, I94r. The Ramspeck bill was immediately offered as an amendment. At that point, however, Representative Smith of Virginia offered a substitute for the Ramspeck proposal. By

joining of labor organizations, by the employees of such establishments, nor to prevent the National Defense Mediation Board from urging, or any umpire from granting, under the machinery provided in this title, improvement of their situation in the matter of wages, hours of labor, or other conditions, as shall be found desirable from time to time. (Italics supplied.)

"See p. 506, supra.

o6 H. R. REP. No. 427, pt. 3, 77th Cong. Ist Sess. (1941). $6 \times 37$.

${ }^{0}$ H. R. REP. No. I458, 77th Cong., Ist Sess. (194I), published on November 28, reporting on H. R.

\footnotetext{
See p. 511, supra.
} 
parliamentary procedure, it was therefore in order to consider the Smith proposal before coming to the Ramspeck bill at all. The net result was that the Smith substitute finally passed the House and the Ramspeck bill was never directly considered.

In many respects, Smith's bill went much farther than the original Vinson bill. In addition to the mediation procedure already outlined, it attacks the problem of subversive elements from the position of limitation on union membership and office (discussed in the first section of this survey). Thus:

Sec. rA. Any labor organization which knowingly or negligently permits any member of the Communist Party of the United States, or the Young Communist League, or member of the German-American Bund, or the Kyffhäuserbund, or any person who has been convicted of a felony involving moral turpitude to hold office, appointive or elective, in such labor organization shall cease to have and cease to be entitled to the status of a labor organization under the National Labor Relations Act so long as such person continues to hold office.

An entirely new provision was added providing for a secret ballot, supervised by the United States Conciliation Service, as a prerequisite before a union can give a strike notice $\left(\$_{3}\right)$. Another new provision entitled "Violence and Intimidation" restricts picketing at plants ${ }^{58}$ and forbids it at any person's residence. ${ }^{60}$

During the debate, Representative Hobbs introduced an amendment prohibiting importation of picketers or strikebreakers, which was successful. ${ }^{00}$ To fill out the picture, Section 6 attempts to outlaw boycotts, sympathy strikes, and jurisdictional disputes. $^{81}$

${ }^{8 s} \mathrm{Sec} .5$ (a) It shall be unlawful for any person, by the use of force or violence or threats thereof, to prevent or to attempt to prevent any individual from accepting employment by, or continuing in the employment of, any defense contractor, or from entering or leaving any place of employment of such contractor in the course of such employment.

${ }^{80}$ (b) Notwithstanding any other provision of the Act, it shall be unlawful for one or more persons, for the purpose of inducing any person to work or abstain from working for a defense contractor, to watch or beset a house or place where a person resides or the approach to such house or place.

${ }^{\text {co }}$ (c) It shall be unlawful, notwithstanding any other provision of law, for one or more persons acting in contemplation of furtherance of a labor dispute to attend at or near a place where a defense contractor carries on business, for the purpose of obtaining or communicating information, or of persuading or inducing any person to work or abstain from working, unless such persons so attending, were, immediately prior to the beginning of such labor dispute, bona fide employees of such contractor, or for a defense contractor to employ any person who is to be employed for the purpose of obstructing or interfering by force or threats (I) with peaceful picketing of employees during any labor dispute affecting wages, hours, or conditions of labor, or (2) the exercise by employees of any of the rights of selforganization or collective bargaining. Mich.).

The prohibition against strikebreakers was added on the floor at the suggestion of Rep. Hook (Dem.,

${ }^{e x}$ Sec. 6 (a) It shall be unlawful, by means of a strike against a person (whether or not a defense contractor), or by means of a concerted refusal to work on, handle, or otherwise deal with articles or materials produced or manufactured by any such person, to induce or require or attempt to induce or requirc another person who is a defense contractor to recognize, deal with, comply with the demands of, or employ members of, any labor organization.

(b) It shall be unlawful, by means of a strike against a defense contractor, or by means of a concerted refusal to work on, handle, or otherwise deal with articles or materials purchased, produced, manufactured, or used by a defense contractor, to induce or require or attempt to induce or require such contractor to recognize, deal with, comply with the demands of, or employ members of, one labor organization instead of another labor organization with which such contractor has an applicable collective. bargaining agreement. 
Another major innovation in the Smith substitute is its multi-method enforcement provision. For any violation, an injunction may be had, notwithstanding the NorrisLa Guardia Act $(\$ 7(a))$, or a civil damage suit may be maintained $(\$ 7(b))$. In addition, any employee who violates the Act loses his status under the NLRA, his right to any federal relief, and his right to unemployment compensation under the Social Security Act $(\$ 7(c))$, and any organization violating the Act or retaining as its officer or representative any violator of the Act loses its status under the NLRA and the Norris-La Guardia Act ( $\$ 7(\mathrm{~d})$ and $(e))$.

Finally, the Smith substitute throws in a registration provision very similar to the one discussed above in connection with H. R. 6444 .

The scope and extent of these additions no doubt speak for themselves. It should be emphasized that they passed the House at a period when public opinion was at the peak of distress reached during John L. Lewis' defiant stand in the captive coal dispute. During the debate it was reiterated by supporters that the Nation was insisting on action. Opponents stressed the headlong haste and lack of thought with which the proposals were being pushed to a vote, and especially emphasized the fact that no hearings of any sort were held on any of Smith's proposals. ${ }^{82}$ The separate vote on the Smith substitute amendment was 229 for, $15^{8}$ against. Ramspeck moved to recommit the bill to the Committee on Naval Affairs with instruction to substitute his measure, but Representative Rankin (Dem., Miss.) was sustained in the point that the motion to recommit was out of order since "a motion to recommit cannot contain instructions to amend an amendment which has just been adopted by the House." Floor consideration of the Labor Committee's proposal was thus procedurally impossible, and the vote on the bill, as amended, was 252 to $13^{6}$. It is impossible to read the history of this bill without being impressed by the astuteness with which parliamentary rules were enlisted as an ally by its supporters.

The Senate Committee on Education and Labor to which the bill was referred has taken no action on it, and since that committee has informally taken the position that further legislation is inadvisable until the War Labor Board has shown its mettle, it does not seem likely that the immediate future will bring new developments.

As late as May, I942, however, a subcommittee of the House Committee on the Judiciary was concluding hearing on H. R. 52I8, a bill by Mr. Walter "to confer jurisdiction on United States courts in cases involving work stoppages for non-labor purposes" but these hearings have not been published (at this writing) and no committee report has been forthcoming.

02 87 Cong. Rec., December 3, I941, at $9613-9636$, contains the general debate. 